\title{
Plasma LH concentrations after single or double injections of synthetic LH-RH in dairy cows
}

\author{
J. P. Foster \\ Department of Physiology and Environmental Studies, University of Nottingham School of Agriculture, \\ Sutton Bonington, Loughborough, Leics LEI2 SRD, U.K.
}

\begin{abstract}
Summary. Milked Friesian dairy cows were given 1 or 2 i.v. injections of synthetic LH-RH. The second of 2 injections of LH-RH given $1.5 \mathrm{~h}$ apart induced a significantly greater release of $\mathbf{L H}$ than did the first. The response to this injection was also significantly greater than that caused by injections given $6 \mathrm{~h}$ apart. There was no significant difference between the $\mathrm{LH}$ responses to the two injections given $6 \mathrm{~h}$ apart. The total $\mathrm{LH}$ release produced by the two injections of $100 \mu \mathrm{g}$ synthetic LH-RH given $1.5 \mathrm{~h}$ apart was significantly greater than that produced by single injection of $200 \mu \mathrm{g}$ synthetic LH-RH. It is concluded that there is a short-term increase in the responsiveness of the bovine pituitary gland to LH-RH after an initial LH-RH stimulus.
\end{abstract}

\section{Introduction}

In the sheep multiple injections of synthetic LH-RH induce a much greater release of LH, as assessed by height, area and duration of the induced LH peak, than does a single injection of the same total dose (Crighton, Foster, Haresign \& Scott, 1975). Furthermore, the second of two appropriately spaced injections of LH-RH induces a greater release of $\mathrm{LH}$ than does the first in the rat (Aiyer, Chiappa \& Fink, 1974) and the sheep (Crighton \& Foster, 1977), indicating that LH-RH has the ability to sensitize the anterior pituitary gland to further LH-RH stimulation in these species. In the sheep this sensitizing effect is only apparent for approximately $3 \mathrm{~h}$ after the initial exposure to LH-RH because the second injection induces a significantly smaller $\mathrm{LH}$ response than does the first when it is given 6, 12 or $24 \mathrm{~h}$ later (Crighton \& Foster, 1977). In the present experiment the effect of an initial injection of LH-RH on the subsequent pituitary response to LH-RH by dairy cows was investigated.

\section{Materials and Methods}

Cyclic Friesian dairy cows were used when they were 70-105 days after calving (mid- to late lactation). They were housed tied in indoor stalls and milked twice daily. Oestrous cycles were monitored by the measurement of progesterone concentration in milk samples, obtained three times weekly, by the radioimmunoassay method of Lamming \& Bulman (1976). All cows were treated during the midluteal stage of the oestrous cycle. A jugular venous catheter was placed in each animal on the day before treatment. Three treatment groups were used. In Group 1, 4 cows received 2 intravenous (i.v.) injections, each of $100 \mu \mathrm{g}$ synthetic LH-RH (Hoechst Pharmaceuticals Ltd) in $2 \mathrm{ml}$ saline $(0.9 \%(\mathrm{w} / \mathrm{v})$ $\mathrm{NaCl}$ ), given $1.5 \mathrm{~h}$ apart. The 3 cows in Group 2 received 2 i.v. injections, each of $100 \mu \mathrm{g}$ synthetic LH-RH in $2 \mathrm{ml}$ saline, $6 \mathrm{~h}$ apart. A single i.v. injection of $200 \mu \mathrm{g}$ synthetic LH-RH in $4 \mathrm{ml}$ saline was given to the 4 animals in Group 3. A blood sample was taken from each cow every $10 \mathrm{~min}$ from $30 \mathrm{~min}$ before the first until $10 \mathrm{~h}$ after the second or only injection. Plasma from these samples was stored at $-20^{\circ} \mathrm{C}$ until assayed for $\mathrm{LH}$ by a double-antibody radioimmunoassay previously described by Webb, Lamming, Haynes, Hafs \& Manns (1977). The assay had no significant cross-reaction with other pituitary hormones and had a sensitivity of $0.2 \mathrm{ng}$ NIH-LH-B9 equivalents $/ \mathrm{ml}$. The inter- and intra-assay coefficients of variation were 13 and $9 \%$ respectively. 


\section{Results}

Injection of LH-RH always induced release of LH (Table 1, Text-fig. 1). The size of the LH response was assessed in terms of the area under the induced LH peak when this was plotted on an arbitrary scale on graph paper. The area of the first peak for Group 1 cows may have been underestimated because the plasma LH concentrations had not returned to basal values in 3 of the 4 animals at the time of the second injection.

Table 1. Mean \pm s.e.m. areas (arbitrary units) under the peaks of LH induced by LH-RH in dairy cows

\begin{tabular}{clcccc}
\hline Group & \multicolumn{1}{c}{ Treatment } & $\begin{array}{c}\text { No. of } \\
\text { cows }\end{array}$ & 1st peak & 2nd peak & Total \\
\hline 1 & $100 \mu \mathrm{g} \mathrm{LH-RH}, 1.5 \mathrm{~h}$ apart & 4 & $1582 \pm 466^{*}$ & $6770 \pm 975^{*} \ddagger$ & $8352 \pm 1390 \S$ \\
2 & $100 \mu \mathrm{g}$ LH-RH, $6 \mathrm{~h}$ apart & 3 & $3037 \pm 688 \dagger$ & $1414 \pm 230 \ddagger$ & $4451 \pm 764$ \\
3 & $200 \mu \mathrm{g} \mathrm{LH}-\mathrm{RH}$ & 4 & - & - & $3998 \pm 989 \S$ \\
\hline
\end{tabular}

* Significantly different, $P<0.01$.

$\uparrow$ Significantly different, $P<0.05$.

$\ddagger$ Significantly different, $P<0.01$.

$\S$ Significantly different, $P<0.05$.

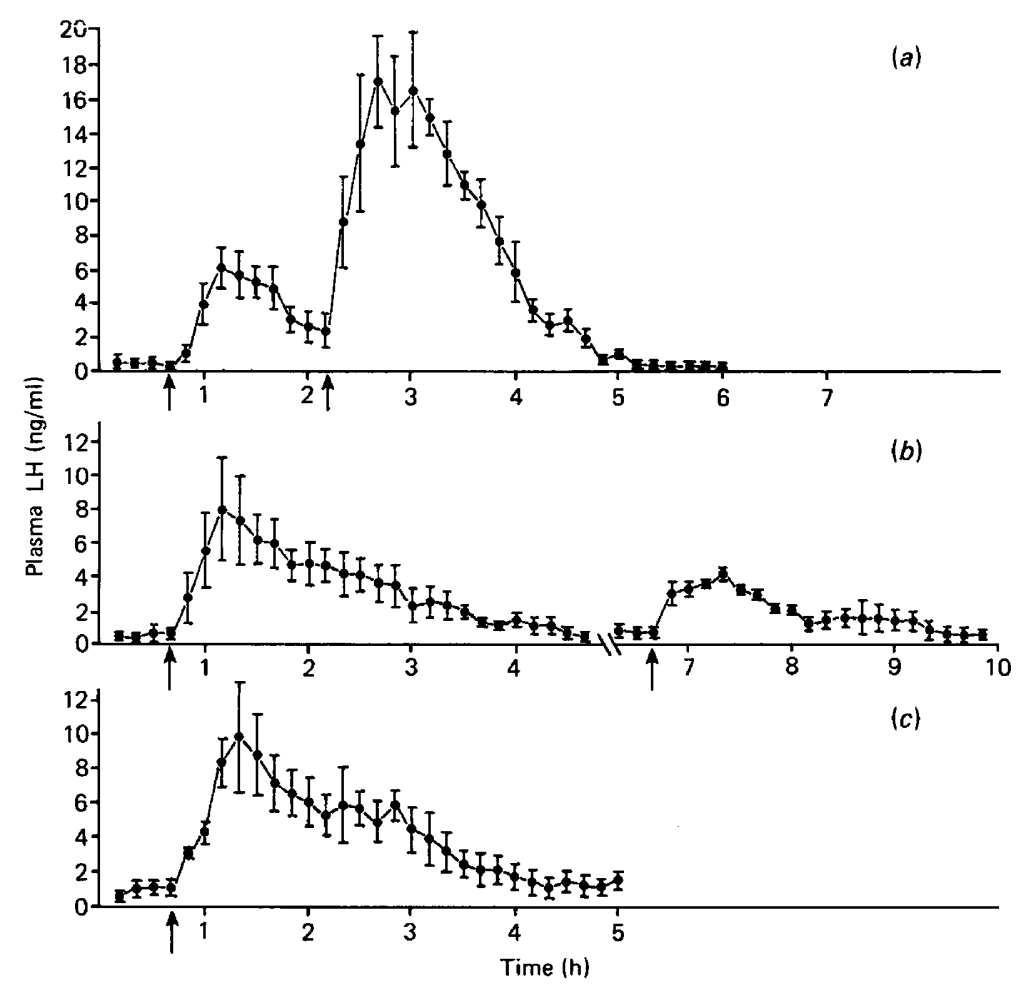

Text-fig. 1. Mean \pm s.e.m. LH concentrations in the jugular venous blood of dairy cows treated with LH-RH (arrows). (a) Group 1, 2 injections of $100 \mu \mathrm{g} \mathrm{LH-RH} \mathrm{1.5} \mathrm{h} \mathrm{apart;} \mathrm{(b)} \mathrm{Group} \mathrm{2,} 2$ injections of $100 \mu \mathrm{g} \mathrm{LH-RH}$ $6 \mathrm{~h}$ apart; (c) Group 3, one injection of $200 \mu \mathrm{g} \mathrm{LH}-\mathrm{RH}$. 


\section{Discussion}

The present results indicate that the response of the bovine pituitary gland to synthetic LH-RH is increased $1 \cdot 5 \mathrm{~h}$ after an initial LH-RH stimulation because injection at this time induced a significantly greater $\mathrm{LH}$ release than did injection given without prior $\mathrm{LH}-\mathrm{RH}$ stimulation. The area under the $\mathrm{LH}$ peak induced by the second injection in Group 1 was not only significantly greater than that induced by the first injection in the same group, in which the response was probably underestimated, but was also significantly greater than that induced by the first injection in Group 2 cows for which the full response could be estimated.

This increased responsiveness to LH-RH was no longer apparent $6 \mathrm{~h}$ after an initial LH-RH stimulation because there was no significant difference between the $\mathrm{LH}$ responses to two injections of synthetic LH-RH given $6 \mathrm{~h}$ apart.

Kittok, Britt \& Convey (1973) gave three doses of $100 \mu$ g synthetic LH-RH at 2-h intervals to Holstein cows with cystic follicles and to cyclic cows in the luteal phase and found that peak serum LH concentrations occurred after the second injection. However, when Kinder, Adams, Chakraborty, Tarnavsky \& Reeves (1975) gave repeated injections of $150 \mu \mathrm{g}$ synthetic LH-RH to Angus heifers at $4 \mathrm{~h}$ intervals the response to the first injection appeared to be greater than that to subsequent injections. These results are consistent with the idea that, as in the sheep (Crighton \& Foster, 1977), there is a short-term increase in the responsiveness of the bovine pituitary gland to $\mathrm{LH}-\mathrm{RH}$ after an initial LH-RH stimulation.

In the present study, the two injections of synthetic LH-RH given $1.5 \mathrm{~h}$ apart caused a significantly greater $\mathrm{LH}$ release than did a single injection of the same total dose, indicating how a prolonged LH-RH stimulus could take advantage of the sensitization effect to induce a greater LH release than a single stimulus. In untreated animals, endogenous LH-RH stimulation at oestrus perhaps sensitizes the pituitary gland to further LH-RH stimulation and thereby helps to ensure that an adequate preovulatory LH release occurs at this time.

This work was supported by a grant from the Agricultural Research Council. I thank Hoechst Pharmaceuticals and the National Institutes of Health, U.S.A., for hormone preparations and Miss S. K. Lam for her skilled technical assistance.

\section{References}

AIYeR, M.S., ChIAPPa, S.A. \& FinK, G. (1974) A priming effect of luteinizing hormone releasing factor on the anterior pituitary gland in the female rat. $J$. Endocr. 62, 573-588.

Crighton, D.B. \& Foster, J.P. (1977) Luteinizing hormone release after two injections of synthetic luteinizing hormone releasing hormone in the ewe. $J$. Endocr. 72, 59-67.

Crighton, D.B., Foster, J.P., Haresign, W. \& Scott, S.A. (1975) Plasma LH and progesterone levels after single or multiple injections of synthetic LH-RH in anoestrous ewes and comparison with levels during the oestrous cycle. J. Reprod. Fert. 44, 121-124.

Kinder, J.E., ADAMS, T.E., Chakraborty, P.K., TARnAvsky, G.K. \& ReEVES, J.J. (1975) Serum LH concentrations and ovarian activity in cows with repetitive administration of LH-RH/FSH-RH. $J$. Anim. Sci. 41, 1650-1652

KITTOK, R.J., BRITT, J.H. \& CONVEY, E.M. (1973) Endocrine response after GnRH in luteal phase cows and cows with ovarian follicular cysts. J. Anim. Sci. 37, 985-989.

LAmming, G.E. \& Bulman, D.C. (1976) The use of milk progesterone radioimmunoassay in the diagnosis and treatment of subfertility in dairy cows. Br. vet.J.132, 507-517.

Webb. R., Lamming, G.E., Haynes, N.B., Hafs, H.D. \& ManNs, J.G. (1977) Response of cyclic and postpartum suckled cows to injections of synthetic LH-RH J. Reprod. Fert. 50, 203-210.

Received 21 December 1977 